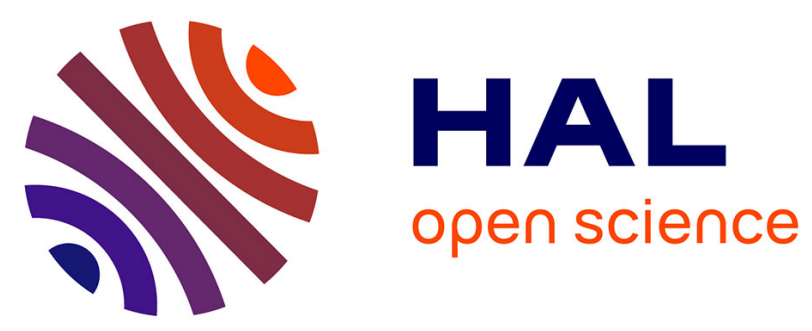

\title{
Syntectonic fluid flow and deformation mechanisms within the frontal thrust of foreland fold-and-thrust belt: Example from the Internal Jura, Eastern France
} Luca Smeraglia, Olivier Fabbri, Flavien Choulet, Martine Buatier, Philippe Boulvais, Stefano Michele Bernasconi, Francesca Castorina

\section{To cite this version:}

Luca Smeraglia, Olivier Fabbri, Flavien Choulet, Martine Buatier, Philippe Boulvais, et al.. Syntectonic fluid flow and deformation mechanisms within the frontal thrust of foreland fold-and-thrust belt: Example from the Internal Jura, Eastern France. Tectonophysics, 2020, 778, pp.228178. 10.1016/j.tecto.2019.228178 . insu-02458963

\section{HAL Id: insu-02458963 \\ https://hal-insu.archives-ouvertes.fr/insu-02458963}

Submitted on 29 Jan 2020

HAL is a multi-disciplinary open access archive for the deposit and dissemination of scientific research documents, whether they are published or not. The documents may come from teaching and research institutions in France or abroad, or from public or private research centers.
L'archive ouverte pluridisciplinaire HAL, est destinée au dépôt et à la diffusion de documents scientifiques de niveau recherche, publiés ou non, émanant des établissements d'enseignement et de recherche français ou étrangers, des laboratoires publics ou privés. 


\section{Journal Pre-proof}

TEETONOPHYSICS

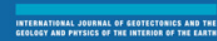

Syntectonic fluid flow and deformation mechanisms within the frontal thrust of foreland fold-and-thrust belt: Example from the Internal Jura, Eastern France

Luca Smeraglia, Olivier Fabbri, Flavien Choulet, Martine Buatier, Philippe Boulvais, Stefano M. Bernasconi, Francesca Castorina

$\begin{array}{ll}\text { PII: } & \text { S0040-1951(19)30285-9 } \\ \text { DOI: } & \text { https://doi.org/10.1016/j.tecto.2019.228178 }\end{array}$

Reference: $\quad$ TECTO 228178

To appear in:

Received Date: $\quad 7$ May 2019

Revised Date: 28 July 2019

Accepted Date: 18 August 2019

Please cite this article as: Smeraglia L, Fabbri O, Choulet F, Buatier M, Boulvais P, Bernasconi SM, Castorina F, Syntectonic fluid flow and deformation mechanisms within the frontal thrust of foreland fold-and-thrust belt: Example from the Internal Jura, Eastern France,

Tectonophysics (2019), doi: https://doi.org/10.1016/j.tecto.2019.228178

This is a PDF file of an article that has undergone enhancements after acceptance, such as the addition of a cover page and metadata, and formatting for readability, but it is not yet the definitive version of record. This version will undergo additional copyediting, typesetting and review before it is published in its final form, but we are providing this version to give early visibility of the article. Please note that, during the production process, errors may be discovered which could affect the content, and all legal disclaimers that apply to the journal pertain.

(c) 2019 Published by Elsevier. 


\section{Syntectonic fluid flow and deformation mechanisms within the frontal thrust of foreland fold-and-thrust belt: example from the Internal Jura, Eastern France}

Luca Smeraglia ${ }^{1,2}$, Olivier Fabbri ${ }^{1}$, Flavien Choulet $^{1}$, Martine Buatier ${ }^{1}$, Philippe Boulvais ${ }^{3}$, Stefano M. Bernasconi ${ }^{4}$, Francesca Castorina ${ }^{2}$

1. Chrono-Environnement, UMR 6249, Université de Franche Comté-CNRS, 25000 Besançon, France

2. Dipartimento di Scienze della Terra, Sapienza Università di Roma, P.le Aldo Moro 5, 00185, Roma, Italy

3. Géosciences Rennes, CNRS, UMR 6118, Université de Rennes, F-35000 Rennes, France

4. Geological Institute, ETH Zürich, Sonneggstrasse 5, 8092 Zürich, Switzerland

Luca Smeraglia*: luca-smeraglia@uniroma1.it

Olivier Fabbri: olivier.fabbri@univ-fcomte.fr

Flavien Choulet: flavien.choulet@univ-fcomte.fr

Martine Buatier: martine.buatier@univ-fcomte.fr

Philippe Boulvais: philippe.boulvais@univ-rennes1.fr

Stefano M. Bernasconi: stefano.bernasconi@erdw.ethz.ch

Francesca Castorina: francesca.castorina@uniroma1.it 


\section{Highlights}

- -Frontal thrusts act as a conduit for infiltration of meteoric-derived fluids

- -Calcite precipitation occurred at temperatures between $10^{\circ}$ and $54{ }^{\circ} \mathrm{C}$

- -Layer-parallel shortening and shear occurred during folding

- $\quad$-Pressure-solution, frictional sliding, and veining occurred during thrusting

- -Slow deformation along thrust is consistent with aseismic growth of Jura anticline

Abstract: Structural mapping and microstructural analyses are combined with stable, clumped, and radiogenic isotopes to unravel deformation mechanisms and syntectonic fluid flow during upward propagation along the Fuans frontal thrust of the internal part of the Jura fold-andthrust belt. The Fuans thrust cuts through Upper Jurassic-Lower Cretaceous carbonate deposits, branches into two splays, and generates a system of fault-propagation folds. Folding was accomodated by layer-parallel shortening and layer-parallel shear, which generated flexural slip along bedding surfaces, stylolites, and foliated fabric in marly limestone interbeds. Thrusting was characterized by cycles of mutually overprinting ductile pressure-solution and brittle processes such as frictional sliding and fracturing/veining. This generated foliated tectonites in marls and limestones without significant cataclasis of the host rock. Pressure-solution and micrometer slip along slickenfibers are evidence of aseismic slip, in agreement with the ongoing aseismic anticline growth within the Jura fold-and-thrust, while crackle-like vein texture may account for episodic seismic fracturing. Geochemical data show that Fuans thrust acted as a conduit for the downward infiltration of meteoric-derived fluids, which channelized along foliated tectonites during syntectonic fluid flow. Calcite mineralizations precipitated at temperatures between $54{ }^{\circ} \mathrm{C}$ and 10 
${ }^{\circ} \mathrm{C}$, showing an increased contribution of carbon derived from organic carbon respiration in soils in colder paleofluids. This indicates a progressive opening of the system, characterized by a more efficient and extensive meteoric fluids circulation. Considering the highest recorded temperature of $54{ }^{\circ} \mathrm{C}$ and assuming the modern geothermal gradient of $30{ }^{\circ} \mathrm{C} / \mathrm{km}$, thrusting in the exposed outcrop initiated at burial depths of at least $\sim 1.4 \mathrm{~km}$.

Key words: fluid-rock interaction, fold-and-thrust belt, stable radiogenic and clumped isotopes, calcite veins, 2D kinematic model, fault-propagation fold

\section{Introduction}

Foreland fold-and-thrust belts are generated by thrusting and folding of the sedimentary cover at diagenetic P-T conditions $\left(\mathrm{T}<300^{\circ}\right.$ and $\mathrm{P}<200 \mathrm{MPa}$; Davis et al., 1983), thus reaching the optimal conditions of hydrocarbon generation (14\% of the world's discovered reserves of hydrocarbons, Cooper et al., 2007) and disruptive earthquakes nucleation ( $\mathrm{M}$ > 8.0; Nissen et al., 2011). In this context, thrust faults, the major structures forming fold-and-thrust belts, may act as conduits or barriers for crustal fluid flow (Lacroix et al., 2014), including hydrocarbons, and may be sites for earthquakes nucleation and upward propagation (Kodaira et al., 2012).

The rheology of the different rock types involved during thrusting affect deformation styles (i.e. brittle vs. ductile) and consequently, thrust-related permeability structure (fracture orientation and connectivity, fault rocks permeability), fluid pressure fluctuations (hydrostatic to nearlithostatic pressure), and fault slip behaviors (seismic vs. aseismic) (Faulkner et al., 2010; Lèclère et al., 2015). Therefore, the study of syntectonic veins, fault zone structure and deformation mechanisms is of interest both for hydrocarbon resources and for earthquake hazard assessment, in order to constrain the P-T conditions during fluid flow and paleo-hydrology along thrust faults (Lacroix et al., 2011), to understand the fluid transport in potential reservoirs (i.e. thrust-related 
folds, Beaudoin et al., 2015), and earthquake nucleation and propagation processes along seismogenic thrusts (Tesei et al., 2013).

Numerous studies have extensively investigated these topics along thrusts and folds exhumed from the hinterland and most deformed parts of fold-and-thrust belts, such as those of Pyrenees (Travé et al., 1998; Lacroix et al., 2014), Apennines (Vannucchi et al., 2010; Ghisetti et al., 2001), Wyoming (Beaudoin et al., 2011), and Canadian Rockies Mountains (Kirschner and Kennedy, 2001), among many others. However, due to low exhumation/erosion rates or burial, only few field studies dealt with P-T conditions of syntectonic fluid flow and deformation mechanisms within the frontal thrust of foreland fold-and-thrust belts (Vrolijk et al., 1991; Labaume et al., 1997; Crognier et al., 2017). In particular, frontal thrusts can act as conduit for the downward infiltration of meteoric-derived fluids and can promote hydrocarbon migration and potential accumulation during orogenesis (Fitz-Diaz et al., 2011). Therefore, such studies are still needed to document the permeability structure of frontal thrusts, which may act as conduits for hydrocarbon migration into shallow reservoirs, and to unravel fault slip behaviors, which may affect both earthquakes nucleation and seismic slip upward propagation, often causing surface or seafloor breakthrough associated with tsunami generation.

The purpose of this study is to understand the deformation mechanisms, thrust and folds development, paleo-hydrology (fluid origin, paleotemperatures, and pathways), and the burial conditions during fluid flow and deformation within the frontal thrust of an active fold-and-thrust belt. To do so, we study the frontal thrust of the internal part of the Jura foreland fold-and-thrust belt (Eastern France; Fig. 1) combining geological mapping and structural analyses with optical and cathodoluminescence microscopy, mineralogy of fault rocks, stable, clumped, and radiogenic isotopes of fault-related mineralization. The Jura foreland fold-and-thrust belt can be considered as an archetypal of foreland fold-and-thrust belts (Affolter and Gratier, 2004) and is an ideal place where study thrust development and thrust-fluid interaction. Therefore, results from this study can be easily compared to similar fold-and-thrust belts worldwide. 


\section{Geological setting}

\subsection{The Jura foreland fold-and-thrust belt}

The Jura fold-and-thrust belt is located in the foreland of the Western Alps and was formed since the Late Miocene by the ongoing continental collision of the Eurasian plate below the African plate or Africa-derived microplate (Affolter and Gratier 2004; Fig. 1a). Shortening affected the 2,000-2,500 m thick Triassic-Late Miocene sedimentary succession deposited above the Hercynian crystalline basement (Becker, 2000; Sommaruga, 1996). The sedimentary succession starts with Triassic rocks, which consists of $\sim 500-1,000$ m thick conglomerates, marls, carbonates, and evaporites (anhydrite and salt) deposited into shallow water continental to marine environments (Fig. 1a). These deposits are followed by $\sim 1,500 \mathrm{~m}$ thick Jurassic-Early Cretaceous succession of massive to bedded limestones, marls, and clays (Fig. 1a). Following a PaleoceneEocene regional unconformity formed, Oligocene-Miocene shallow marine to continental clastic deposits of the Molasse basin were deposited above Early Cretaceous limestones. The thickness of the Molasse basin deposits increases towards the SE, reaching $\sim 4,000 \mathrm{~m}$ in the basin depocenter, whereas in the Jura the maximum preserved thickness is $\sim 100 \mathrm{~m}$ (Fig. 1a).

After an Oligocene extensional tectonic phase, NW-SE shortening started in the Late Miocene and generated the Jura fold-and-thrust belt (Philippe et al., 1996; Ustaszewski and Schmid, 2006). Shortening was accomodated by NE-SW-trending and N- to NW-verging thrust faults, by NW-SE- to N-S-trending strike-slip faults, and by NE-SW-trending anticlines and synclines (Sommaruga, 1996; Fig. 1a,b). In spite of intensive research, there is still an active debate if the Juras is the result of pure thin-skinned tectonics or if there is an involvement of the basement (for review see Sommaruga, 1996). Some authors, based on seismic reflection profiles, suggest a thin-skinned tectonics with the basal décollement located within Triassic evaporites and several décollements located within Lower-Middle Jurassic marls and shales (i.e. Opalinus Ton; Sommaruga, 1996; Malz et al., 2015) (Fig. 1). However, since late Pliocene, a change from thin- 
skinned to thick-skinned compressional tectonics was suggested (Ustaszewski and Schmid, 2006; Madritsch et al., 2008), with the re-activation of pre-existing Paleozoic and Paleogene basementhosted faults (Giamboni et al., 2004).

Deformation in the Jura Mountains is still active and instrumental seismology shows that strike-slip earthquakes $(\mathrm{M}<5.5)$ occur along NW-SE- to NNW-SSW strike-slip faults with hypocenters at $\sim 1-5 \mathrm{~km}$ depths, both in the sedimentary cover and in the upper part of the crystalline basement (Thouvenot et al., 1998). Thrust-related earthquake also occurred (2004 Besançon earthquake, Baer et al., 2005), with hypocenter located at $\sim 15 \mathrm{~km}$ depth in the crystalline basement (Madritsch et al., 2008). Geodetic and geological data indicate a N-S- to NNW-SSE-oriented and up to $\sim 1 \mathrm{~mm} / \mathrm{a}$ ongoing shortening coupled with $\sim 0.5 \mathrm{~mm} / \mathrm{a}$ of uplift (Becker, 2000; Walpersdorf et al., 2006; Ziegler and Fraefel, 2009; Madritsch et al., 2010). More precisely, uplift is located above main thrusts and anticlines, suggesting both thrust- and foldrelated shortening (Ziegler and Fraefel, 2009; Madritsch et al., 2010). However, thrust-related earthquake has been recorded only in the crystalline basement (2004, Besançon earthquake; Baer et al., 2005), suggesting that, at least in the sedimentary cover, anticline growth is mainly accommodated by aseismic deformation (Madritsch et al., 2010).

\subsection{Geology of the Fuans area}

The frontal thrust of the internal part of the Jura fold-and-thrust belt, close to Fuans village (hereafter Fuans thrust; Figs. 1a,b and 2), is the focus of this study. In this area, the exposed Mesozoic sedimentary succession is characterized by $\sim 500 \mathrm{~m}$ thick Upper Jurassic deposits overlain by $\sim 50 \mathrm{~m}$ thick Lower Cretaceous deposits (Fig. 2). From the base to the top, the Upper Jurassic deposits consist of Oxfordian marls and marly limestones, with an interbed of $\sim 80 \mathrm{~m}$ thick massive limestones, $\sim 170 \mathrm{~m}$ thick massive Kimmeridgian limestones overlain by a marl to marly limestone interval, and of $\sim 100$ m-thick Tithonian well-bedded limestones. The Lower Cretaceous (Berriasian-Valanginian) deposits consist of $\sim 20 \mathrm{~m}$-thick marls and marly limestones 
with gypsum lenses overlain by $\sim 30$ m-thick well-bedded limestones. In the Fuans area, the clastic deposits of the Molasse basin are not preserved. The Upper Jurassic deposits are thrusted over the Lower Cretaceous deposits by the Fuans thrust (Fig. 2).

A complete stratigraphic section located $\sim 25 \mathrm{~km}$ towards the SE (Val de Ruz section, Fig. 1; Sommaruga, 1996) allows to observe the lower part of the succession not exposed in the Fuans area. In particular, below the Oxfordien deposits, the succession consists of $\sim 50 \mathrm{~m}$-thick Callovian limestones, $\sim 40$ m-thick Bathonian marls, $~ 120$ m-thick Bajocian limestones, $\sim 90$ m-thick Aalenian shales (i.e. Opalinus clay), $\sim 140$ m-thick Lower Jurassic marls, and $\sim 800 \mathrm{~m}$-thick Triassic anhydrites, marls, and shales (Fig. 1). In the Val de Ruz section, the clastic deposits of the Molasse basin are 120 m-thick (Fig. 1).

\section{Methods}

The following methods were used: (1) geological field mapping at 1:10,000 scale or larger and structural analyses to calculate the paleostress tensor (using Win-Tensor software, Delvaux and Sperner, 2003); (2) cross-sections and 2D kinematic forward modelling to reconstruct the faultfold geometry observed in the field (using MOVE 2017.2, Midland Valley Ltd.); (3) microstructural analyses with optical microscope and cathodoluminescence to unravel deformation mechanisms and fluid circulation; (4) stable isotopes (carbon and oxygen, performed at the Isotopic Geochemistry and Geochronology laboratory, University of Rennes 1), carbonate clumped isotopes (performed at ETH Zürich), and radiogenic isotopes (strontium, performed at Istituto di Geologia Ambientale e Geoingegneria-CNR laboratory, Sapienza University of Rome) to unravel the precipitation temperatures and composition of syn-tectonic fluids; (5) X-ray diffraction analysis (XRD, performed at Chrono-Environnement laboratory, University of Franche-Comté) to determine whole-rock mineralogical composition and clays mineralogy of marly and clayey interbed within the host rocks and of clay localized along minor thrust faults. Methodologies and analytical details are described in the Supplementary Material. 


\section{Results}

\subsection{Mapping and structural analyses}

This study was focused along a $\sim 1.5 \mathrm{~km}$-long roadcut (regional road D461), which exposes the internal structure of the Fuans thrust zone. There, the E- to SE-dipping Fuans thrust juxtaposes Kimmeridgian deposits above Tithonian-Valanginian deposits, with displacement ranging between $\sim 400$ and $\sim 500 \mathrm{~m}$ (Fig. 2). The thrust zone is characterized by a recumbent syncline, located in the footwall, and by an overturned syncline and an upright anticline, both located in the hanging-wall (Figs. 2 and 3a).

The Fuans thrust juxtaposes the overturned hanging-wall syncline above the S- to SEdipping recumbent limb of the footwall syncline (Fig. 3a). The recumbent limb of the footwall syncline is offset by minor reverse faults (Fig. 3a,c), characterized by kinematic indicators showing dip-slip reverse to left-lateral compressional displacements (Fig. $3 b$ plot 1,2). The Fuans thrust is characterized by thrust planes showing left-lateral compressional displacements (Fig. $3 b$ plot 3) and by strike-slip faults showing dextral movements (Fig. 3b plot 4).

The overturned hanging-wall syncline is characterized by WNW-dipping $\left(10^{\circ}-30^{\circ}\right)$ upright limb and by a S- to SE-dipping $\left(35^{\circ}-80^{\circ}\right)$ overturned limb (Figs. 3a, 3e-h). Bedding surfaces display evidence of shear, with kinematic indicators showing both right-lateral and left-lateral extensional displacements within the upright and overturned limbs, respectively (Figs. $3 \mathrm{~h}$ and S1a). The syncline hinge is cut by reverse and normal faults and by sheared bedding surfaces with unclear kinematics (Figs. 3e-g, 4b plot 2 and 3, 4c,d and S1b). Normal faults are characterized by kinematic indicators showing dip-slip normal to right-lateral normal displacements and, in places, their attitudes are roughly parallel to the bedding of the overturned limb (Figs. 4b plot 2).

The upright limb is cross-cut by (1) strike-slip faults showing both sinistral and dextral displacements (Fig. 4b plot 1), (2) reverse faults showing dip-slip reverse and right-lateral reverse displacements (Fig. 3h), and by (3) normal faults showing dip-slip normal and right-lateral normal 
displacements (Fig. 4b plot 3 and S1c). In particular, reverse faults branch upward from bedding surfaces characterized by flexural slip (Fig. 3h). Often, these faults show unclear crosscutting relationships. However, where crosscutting relationships are observable, strike-slip faults cut both normal faults characterized by right-lateral normal displacements (Fig. S1c) and the Fuans thrust planes (Fig. S1d-e).

In the upright limb, bedding shows alternating layers of massive limestone and marly limestone, the latter being characterized by anastomosing and bedding-parallel stylolites (Fig. 4e). In places, within marly limestone interbeds, S-CC' fabric occurs (Fig. 4f). Kinematics indicators on S- and C-planes show dip-slip and right-lateral reverse displacements, while C' planes show right-lateral normal displacements (Fig. 4f).

Towards the NE, slope deposits cover the exposure of the overturned syncline and an intensely fractured zone crops out (Fig. 4a,g). The fractured zone is cut by minor reverse faults showing dip-slip reverse to right-lateral reverse displacements and by low-angle strike-slip faults showing dextral displacements (Fig. 4 plot 4). Minor reverse faults are characterized by polished slip surface, which sharply truncate calcite clasts of the surrounding breccia (Fig. 4h). In places, clay-rich layers, up to a few centimeters thick, are localized along minor reverse faults (Fig. 4h).

Further $\mathrm{N}$, the forelimb of the hanging-wall anticline is characterized by NW-dipping shallow- $\left(5^{\circ}-45^{\circ}\right)$ to steeply-dipping $\left(45^{\circ}-90^{\circ}\right)$ limbs (Fig. 5a,c,e). The limbs display evidence of flexural slip on bedding surfaces (Fig. 5c). In places, stylolites oriented roughly perpendicular respect to bedding occur (Figs. 5c and S1f). The anticline forelimb is cross-cut by (1) strike-slip faults showing dextral and sinistral displacements (Fig. 5 plot 1), (2) gently-dipping reverse faults showing both left-lateral and right-lateral reverse displacements (Fig. 5 plot 2), (3) subvertical reverse faults, oriented roughly perpendicular respect to bedding, showing dip-slip reverse displacements (Fig. 5 plot 3), and by (4) normal faults showing dip-slip normal and right-lateral normal displacements (Fig. 5 plot 4). All these faults show unclear crosscutting relationships. However, the normal faults (Fig. 5 plot 4) occur in association with subvertical reverse faults (Fig. 
5 plot 3). In addition, these reverse faults show both wrinkled fault surfaces, typical of stylolitic surfaces, and mechanical striation (Fig. S1g).

The Fuans thrust cross-cuts through the vertical forelimb of the hanging-wall anticline and the overturned limb of the footwall syncline (Fig. 5a,e-h), and shows left lateral compressional movements (Fig. 5b plot 5). In places, thrust planes show evidence of left-lateral normal and sinistral movements (Fig. 5b plot 6). Within the thrust core, S-C and S-CC' fabric occur both in marls and limestones (Fig. 5h). Kinematics indicators on S-planes show dip-slip reverse displacements, on C-planes show dextral and right-lateral reverse displacements, and on C' planes show dip-slip normal and right-lateral normal displacements (Fig. 5h). In places, the Fuans thrust cuts across strike-slip faults located in the overturned limb of the footwall syncline (Fig. S1h). Due to the excellent exposure conditions, microstructural analyses of fault rocks and sampling of fault-related mineralizations were carried out in this outcrop.

\subsection{Microstructures}

The Fuans thrust cuts the vertical beds of the hanging-wall anticline forelimb (Fig. $5 \mathrm{~g}$ and 6a), is characterized by S-C and S-CC' foliated tectonites in marl and limestone (Fig. 6b-e), and branches into two splays, which delimit a limestone lense (Figs. 5g,h and 6a) mostly affected by calcite veins (Fig. 6b,j).

The foliated tectonites show a solution cleavage with dissolution seams aligned along S-, C-, and C'-planes (Fig. 6b-e,h,i). At the microscale, dissolution seams show either teeth-shaped or flat morphologies formed by brown/dark and up to $2 \mathrm{~mm}$-thick seams filled by insoluble materials, such as of phyllosilicates (Fig. 7a-d). Dissolution seams are pervasive and densely-spaced in marl (Figs. 6b,c,g), while they generate a more diffuse network in limestone (Figs. 6d,e,h,i). They delimit lozenge-shaped sigmoids or planar layers of marls, limestones, and clasts of reworked tectonites (Figs. 6g-i and 7a-d). Within the thrust zone four types of calcite-filled mineralizations 
can be distinguished: (a) veins bounded by dissolution seams, (b) cements, (c) slickenfibers, and (d) veins within the limestone lense.

(a) Veins bounded by dissolution seams occur within foliated tectonite in limestones and consist of up to $\sim 1 \mathrm{~cm}$-thick extensional veins filled with blocky to elongated-blocky crystals, cutting through lozenge-shaped sigmoids of limestones and, in places, crossing dissolution seams (Figs. 6h,i and 7a-f). They are oriented both perpendicular and oblique to dissolution seams and generate a pervasive network, showing black to bright-orange colors under cathodoluminescence light and mutual crosscutting relationships (Figs. 6h,i, 7a-f, and 8e-g).

(b) Cement fills the voids between limestone sigmoids and clasts in foliated tectonite in limestones and consists of blocky to elongated-blocky crystals showing black and bright-orange crystal zonation under cathodoluminescence light (Figs. 7e-g and 8e,g). Cement is affected by dissolution seams, which localize along the cement-clast boundaries or between crystal boundaries (Fig. 7g). In places, veins bounded by dissolution seams cuts through the cement (Fig. 8g).

(c) Slickenfibers occur above S-, C-, and C'-planes (Fig. 6f). They develop along dissolution seams steps and consist of multiple layers of crystals showing blocky to fibrous morphologies and filling microscopic dilational jogs separated by sub-parallel shear surfaces localized along dissolution seams (Fig. 7h and 8a-c). In particular, fibrous crystals show multiple subparallel inclusion bands with micrometer-thick separations occurring at high angles $\left(\sim 60^{\circ}-70^{\circ}\right)$ to the shear surfaces (Fig. 7a-c). Slickenfibers cross-cut veins bounded by dissolution seams and cement (Fig. 7b,c). They show black luminescence under cathodoluminescence light.

(d) Veins within the limestone lense consist of up to $\sim 2 \mathrm{~cm}$-thick extensional veins, not associated with dissolution seams, filled with blocky to elongated-blocky calcite crystals characterized by different colors and crystal zonation under cathodoluminescence light (Figs. 8d and $8 \mathrm{~h}$ ). These veins generate a crackle-like texture, showing inconsistent orientations and mutual cross cutting relationships, and each vein shows a single large opening increment, with no evidence of inclusion bands within crystals (Figs. 8d and 8h). 


\subsection{Stable and clumped isotopes}

Stable and clumped isotopes analyses were performed on Upper Jurassic-Lower Cretaceous host rock, veins bounded by dissolution seams (both oblique and perpendicular to dissolution seams), cements, and slickenfibers, all from foliated tectonites, and of veins within the limestones lense. Results are shown in Fig. 9, listed in Table S2-S3, and are reported in the conventional $\delta$ notation respect to the Vienna Pee Dee Belemnite (VPDB) for $\delta^{13} \mathrm{C}$ and Vienna Standard Mean Ocean Water (VSMOW) for $\delta^{18} \mathrm{O}$. Clumped isotopes are reported in the carbon dioxide equilibration scale $\left(\mathrm{CDES}, 25^{\circ} \mathrm{C}\right)$ with uncertainty in temperature reported at the $95 \%$ confidence level (Fernandez et al. 2017).

The host rocks show a narrow range of $\delta^{13} \mathrm{C}$ values, between $+1.8 \%$ and $+2.2 \%$, and of $\delta^{18} \mathrm{O}$ values, between $+27.2 \%$ and $+27.5 \%$. Such values are typical of Upper Jurassic-Lower Cretaceous marine carbonates in the Jura Mountains (Joachimski, 1994; Strasser et al., 2012). Veins bounded by dissolution seams (both oblique and perpendicular to dissolution seams) and cements show a larger range of $\delta^{13} \mathrm{C}$ values, between $-1.5 \%$ and $+2.6 \%$, and of $\delta^{18} \mathrm{O}$ values, between $+21.6 \%$ and $+24.9 \%$. Slickenfibers show a narrow range of $\delta^{13} \mathrm{C}$ values, between $-1.8 \%$ o and $-2.3 \%$, and of $\delta^{18} \mathrm{O}$ values, between $+22.8 \%$ and $23.7 \%$. Veins within the limestones lense show a narrow range of $\delta^{13} \mathrm{C}$ values, between $+1.1 \%$ and $+1.7 \%$, and of $\delta^{18} \mathrm{O}$ values, between $+23.0 \%$ and $+23.6 \%$.

Fault-related mineralizations are characterized by an average $\delta^{18} \mathrm{O}$ value of $23.3 \pm 0.7 \%$, showing an average $\delta^{18} \mathrm{O}$ depletion of $4.1 \%$ compared to the host rocks (Fig. 9a). Several veins bounded by dissolution seams and cements show also a $\delta^{13} \mathrm{C}$ depletion by up to $3 \%$ compared to the host rocks, whereas all the slickenfibers on average show a $\delta^{13} \mathrm{C}$ depletion of $3.5 \%$ compared to the host rocks (Fig. 9a).

Clumped-isotope data yields $\Delta_{47}$ values between 0.603 and 0.728 (Table S3). Using the calibration equation of Bernasconi et al. (2018) (see Methods), these values correspond to calcite 
precipitation temperatures between $10{ }^{\circ} \mathrm{C}$ and $54{ }^{\circ} \mathrm{C}$ (Table S3). In particular, three veins bounded by dissolution seams precipitated at temperatures between $27 \pm 8{ }^{\circ} \mathrm{C}$ and $54 \pm 8{ }^{\circ} \mathrm{C}$, one cement samples at $48 \pm 8{ }^{\circ} \mathrm{C}$, three slickenfibers at temperatures between $10 \pm 8^{\circ} \mathrm{C}$ and $\sim 26 \pm 6^{\circ} \mathrm{C}$, and a vein within the limestones lense at $32 \pm 5{ }^{\circ} \mathrm{C}$ (Fig. 9b). The $\delta^{18} \mathrm{O}$ paleofluid compositions at the time of calcite precipitation were calculated using the Kim and O'Neil (1997) equation and clumped isotope temperatures. Results show that $\delta^{18} \mathrm{O}$ paleofluid composition was between -1.1\%o and $-7.6 \%$ (Fig. 9b). In particular, paleofluids exhibit a decrease of $\delta^{13} \mathrm{C}$ values with decreasing temperatures (Fig. 9c).

\section{4. ${ }^{87} \mathrm{Sr} /{ }^{86} \mathrm{Sr}$-isotopes}

Slickenfibers, one vein bounded by dissolution seams, and veins within the limestones lense show homogenous ${ }^{87} \mathrm{Sr} /{ }^{86} \mathrm{Sr}$-isotope values of $0.70722-0.70726$ (Table S4). These values are consistent with those of Tithonian-Berriasian carbonates (Upper Jurassic-Lower Cretaceous) and with those of Bajocian-Toarcian carbonates (Middle Jurassic) (0.7070-0.7073; McArthur et al., 2001).

\subsection{Clay mineralogy}

X-Ray diffraction analyses (whole rock composition and $<2 \mu \mathrm{m}$ fraction) were performed on 3 samples of clayey and marly interbeds from Upper Jurassic undeformed host rocks and on 6 samples of clay-rich layers localized along the minor reverse faults (Figs. 3c and 4h). All analyzed samples are characterized by smectite, illite, kaolinite, calcite, and quartz (Figs. S2 and S3). Similar clay assemblages were described in clayey and marly interbeds from Jurassic limestones in the Jura Mountains (Hallam et al., 1991). In particular, illite and quartz indicate a continental origin, as they reflect terrigenous inputs, while smectite and kaolinite reflect chemical weathering of limestone in subaerial warm and humid conditions. 


\section{Discussion}

\subsection{D kinematic forward model}

A 2D kinematic forward model of the Fuans thrust zone was created with the software Move 2017.2 (Midland Valley Ltd, see methods), using the trishear kinematic model (Allmendinger, 1998) to model fault-propagation folds and thrusts breakthrough, which allowed the best reproduction of the fold geometries observed in the field (Fig. 10a). The assumptions for the structural style are defined using original field data and previous studies as follows: (1) the thicknesses of stratigraphic units were constrained using field data and the Val di Ruz section (Sommaruga, 1996); (2) we propose that the Fuans thrust initiated along a flat décollement in the Aalenian shales, a regional décollement horizon in the Jura Mountains (Sommaruga, 1996), and cuts as thrust ramp the overlying succession. We cannot exclude that décollement in the Aalenian shales branches into multiple and deeper décollements within the Triassic evaporites (e.g.; Schori et al., 2015; Malz et al., 2015). However, we modeled the most conservative and shallowest décollement; (3) thrust-related folds initiated as fault-propagation folds before thrust breakthrough. In particular, due to the occurrence of a syncline-anticline pair in the hangingwall (Fig. 10a), we infer the occurrence of a blind thrust splaying from the Fuans thrust in the hangingwall; (4) the base of Mesozoic has a general dip of $2.5^{\circ}$ towards SSE (e.g. Sommaruga, 1996).

In the early stage of deformation, shortening was firstly accomodated by folding above the tip point of the Fuans thrust, leading to the formation of an anticline-syncline pair (Fig. 10b). Change in forelimb dip along strike (Figs. 2a, 3a, 4a, and 5a), distributed microfractures within the limestone lense (Fig. 6j), and pressure solution affecting bedding (Fig. 5c and S1f) are consistent with distributed deformation within the triangular zone that characterized the trishear kinematic model (Hardy and Ford, 1997). Such deformation mechanisms may account for overall forelimb thickening (i.e. through microfractures opening) and thinning (i.e. through pressure solution), as predicted by the trishear model (Grelaud et al., 2000). Further shortening was accomodated by 
fold tightening, followed by Fuans thrust breakthrough across the anticline hinge (Fig. 10c). In this context, minor reverse fault generated in the footwall syncline, splaying from the main thrust (Fig. 10a).

Subsequently, the splay thrust started to branch from the Fuans thrust, and, above its tip point, a new anticline-syncline pair generated in the hanging-wall block (Fig. 10d). Then, further shortening was accomodated by fold tightening and by splay thrust breakthrough across the anticline hinge (Fig. 10e). The proposed model is consistent with geometries observed in the field (compare Figs. 2b and 10a with Fig. 10f).

\subsection{Deformation mechanisms during folds development}

Both layer-parallel shortening and shear promoted fold tightening before thrust breakthrough (Mosar and Suppe, 1992; Tavani et al., 2015). Kinematic indicators along bedding surfaces (Figs. 3h and 5c) are consistent with flexural slip generated by layer-parallel shear during

folding (Fig. 11a; Tanner 1989). Stylolites roughly perpendicular respect to bedding (Figs. 5c and S1f) and the S-CC' fabric within the marly limestone interbeds (Fig. 4f) are consistent with layerparallel shortening (Fig. 11a). In particular, the S-CC' fabric probably generated by shearing the inherited bedding-parallel stylolites (Fig. 4e).

During either thrust breakthrough or folding, further shortening was accomodated by minor reverse faults cutting through the anticline forelimb and hinge (Figs. 5b plot 2,3, and 11d), the syncline hinge (Figs. 3e and 11c) and, or branching upward from sheared bedding surfaces (Figs. $3 \mathrm{~h}$ and 11c). In particular, reverse faults oriented roughly perpendicular to bedding show relicts of stylolitic surfaces on fault planes (Figs. S1g). Due to the similar orientation between these minor reverse faults and stylolites oriented roughly perpendicular to bedding (Figs. 5b plot 3 and 5c), we suggest that stylolites evolved in reverse faults when shortening cannot be further accomodated by subvertical stylolites during pressure-solution processes generated by layer-parallel shortening (Fig. 11d). Mineralogical analyses show that clays localized along minor reverse faults (Figs. 3c 
and 4h) are similar to those within the host rocks (Figs. S2 and S3), suggesting mechanical mixing/smearing of clays between the host rocks and the reverse faults. Clay concentration may have been promoted also by pressure-solution processes (Toussaint et al., 2018).

Processing of fault slip data (see methods and Table S1) resulted in paleostress tensors constraining three stress regimes that occurred in the study area: pure compression (Figs. $3 \mathrm{~b}$ plot 1-3, 4 b plot 4 and $5 b$ plot 2,3,5) and pure strike-slip (Figs. $3 b$ plot 4, 4b plot 1, and 5b plot 1) both characterized by WNW-ESE to NNE-SSW maximum shortening directions, and pure extension characterized by WNW-ESE and NW-SE maximum stretching directions (Figs. 4b plot 2,3 and 5b plot 4,6). In particular, the calculated shortening directions are consistent with the regional NWSE to N-S shortening that affected the Jura fold-and-thrust belt since the Late Miocene (Philippe et al, 1996; Becker, 2000; Ustaszewski and Schmid, 2006; Madritsch et al., 2008). The local variability of maximum compression orientations in the study area (i.e. from WNW-ESE to NNESSW) is consistent with the local fold trends undulation and change of thrust strike (Figs. 3a, 4a and 5a). Although all the detailed crosscutting relationships between measured faults are often unclear, the relative timing between the different regimes may be inferred. Strike-slip faults cut the upright limb of the hangingwall syncline (Figs. $3 \mathrm{~b}$ plot 4 and $4 \mathrm{~b}$ plot 1 ), the steeply dipping anticline forelimb (Fig. 5b plot 1), the anticline hinge (Fig. 5b plot 1), and the Fuans thrust planes (Figs. 3b plot 4 and S1d-e). In addition, evidence of re-activation of the Fuans thrust planes under strike-slip stress regime has been observed (Figs. 5b, compare plot 5 with plot 6 ). Therefore, we suggest that they postdate folding and thrusting. We exclude that, in the study area, strike-slips faults developed before folding, as they do not show bedding-parallel striations, which can be symptomatic of strike-slips faulting before strata tilting during folding (Ustaszewski and Schmid, 2006; Madritsch et al., 2008). This inference is consistent with regional geology, which show that major sinistral strike-slip tear faults that cut across and postdate folds (Sommaruga, 1996) and with instrumental seismicity indicating a present-day strike-slip regime in the Jura fold-and-thrust belt (Thouvenot et al., 1998). However, in places, strike-slip faults are offset by the Fuans thrust 
(Fig. S1h). This suggests that, occasionally, strike-slip regime may have occurred after folding but before thrusting (compare Fig. 11b with Fig. 11c). Generally, due to the different phases of folding and thrusting in the Fuans thrust zone (at least two, Fig. 11), multiple phases of compressional and strike-slip stress regimes may have alternated during deformation.

The pure extensional stress regime in the study area may have occurred either precompression or syn-compression. In particular, the NNE-SSW normal faults (Fig. 5b plot 4) can be interpreted as antithetic shear planes associated to the subvertical minor reverse faults cutting through the hanging-wall anticline forelimb (Fig. 5b plot 3 and Fig. 11d). The NE-SW normal faults cutting the overturned limb of the hanging-wall syncline (Figs. $4 \mathrm{~b}$ plot 2 and $4 \mathrm{~d}$ ) can be interpreted as bedding surfaces sheared as normal faults (Fig. 11c). The normal displacements along these faults are consistent with the extensional kinematics of flexural slip occurring along overturned limb (Fig. 3e,h) suggesting that normal faulting initiated from flexural slip movements (Fig. 11c). Generally, all these features are commonly observed within thrust-related faultpropagation folds (Travé et al., 1998; Gutierrez-Alonso and Gross, 1999; Cawood and Bond, 2018, 2019).

The N-S normal faults in the upright limb of the hanging-wall syncline (Fig. 4 plot 3) are cut by strike-slip faults (Fig. S1c), suggesting that normal faults occurred pre-folding. This is consistent with the occurrence of a pre-Miocene extensional phase that probably affected the Jura area during Oligocene times, before the generation of the Jura fold-and-thrust belt (Giamboni et al., 2004; Ustaszewski and Schmid, 2006).

\subsection{Deformation mechanisms along the Fuans thrust}

The Fuans thrust shows cycles of mutually overprinting pressure-solution and brittle processes, such as frictional sliding and fracturing/veining without significant cataclasis of the host rock (Fig. 12a). This interplay generated foliated tectonites in marls and limestones, while the 
limestone lense between two splays of the Fuans thrust was only affected by brittle fracturing/veining (Fig. 12a).

Pressure-solution produced a network of dissolution seams along foliation planes by limestones dissolution and insoluble materials concentration within dissolution seams (i.e. mainly phyllosilicates; Fig. 7a-c). Pressure-solution in marls (Fig. 6g) was enhanced by the catalyzing effect of clays (Renard et al., 1997) and, in fractured limestones (Fig. 6h,i), by the fracture-related reduction of diffusive mass transfer distances (Gratier et al., 1999). The geometrical relationship between dissolution seams and veins perpendicular to them suggests that both were formed under the same stress regime characterized by shortening sub-perpendicular to the dissolution seams and sub-parallel to the veins. This generate extensional (mode I) vein opening and regulate dissolution seams evolution through time (Fig. 12a; Gratier et al., 1999; 2013). Veins oblique to dissolution seams (Fig. 7a-f), reworked clasts of both foliated tectonites and veins (Fig. 7c,d), mutual crosscutting relationships between veins (Figs. 7a-f), and different cathodoluminescence colors (Fig. 8e-g) suggest multiple events of pressure-solution, veining, and vein reworking during prolonged pure shear related to burial and simple shear deformation related to tectonic shortening (Fig. 12a).

Further strain was accommodated by frictional sliding along dissolution seams, in places by smoothing and dissolving their tooth-shaped margins, and by the generation of sharp shear planes and slickenfibers (Figs. 7h, 8a-c, and 12a). Slickenfibers generated through episodic and micrometer- to millimeter-thick slip increments along dissolution seams steps and by synkinematic calcite precipitation into newly created dilational jogs during slickenfiber growth (Figs. 7h and 12a; Fagereng and Byrnes, 2015; Ukar and Laubach, 2016). In particular, slip increments are testified by inclusion bands occurring at high angles $\left(\sim 60^{\circ}-70^{\circ}\right)$ to the shear surfaces (Figs. $7 \mathrm{~h}$ and $8 \mathrm{a}-\mathrm{c})$.

Brittle-ductile style operates at two different strain rates, with cycles of short-term fracturing (at high strain rate) alternated with long-term pressure-solution (at low strain rate) (Gratier and 
Gamond 1990). Foliated tectonite showing pressure-solution processes are considered as aseismic, promoting ductile elastic strain dissipation and slow tectonic stresses release during aseismic creep (for review see Vannucchi et al., 2019). On the contrary, veins perpendicular to dissolution seams (Fig. 7a,b), veins in the limestone lense (Fig. 8d), and slickenfibers (Figs. 7h and 8a-c) suggest accumulation of elastic strain, which can be released during events of episodic fracturing. In particular, geometrical relationships between veins and dissolution seams, differences in opening increments, and textures between veins and slickenfibers may be potentially related to different fault slip rates (Fagereng and Byrnes, 2015). Due to the genetic link between veins perpendicular to dissolution seams and dissolution seams, these veins probably generated during slow aseismic deformation by brittle microfracturing occurring episodically while long-term and slow ductile pressure solution processes were active (Gratier et al., 2013). In addition, micrometer crack-and-seal opening increments along slickenfibers are likely the product of probably aseismic deformation at slow slip rates (Renard, 2005; Fagereng et al., 2011).

On the contrary, crackle-like vein texture (Fig. 8d and 8h), blocky to elongated blocky crystals (Figs. 7e,f and 8g), single opening increment of veins (Fig. 7e,f, and 8d,g), and the lack of inclusion bands indicating incremental opening (compare Fig. 8a with 8d,h), suggest impulsive brecciation and fractures opening associated to earthquakes (Melosh et al., 2014; Fondriest et al., 2015) and post-kinematic calcite precipitation in a fluid-filled open space (e.g. Ukar and Laubach, 2016). The inference of past earthquakes is consistent also with the occurrence of polished slip surfaces, with truncated calcite clasts, along minor reverse faults within the Fuans thrust zone (Fig. 4h), which may be a signature of seismic faulting (Fondriest et al., 2013).

The Fuans thrust can be used as an exposed analogue to understand the thrust zone structure and deformation processes acting along other thrusts in the Jura Mountains and to explain present geodetic observations. In particular, the observed aseismic anticline growth in the Jura Mountains (Madritsch et al., 2010) may be partly related to slow (i.e. aseismic) deformation processes occurring along thrusts, upward propagating across the sedimentary cover. The associated 
aseismic deformation along thrust is in agreement with pressure-solution processes and micrometer slip along slickenfibers within the Fuans thrust (Fig. 10a). However, thrust-related earthquake occurred in 2004 in the Jura Mountains (Besançon earthquake, Baer et al. 2005). Accordingly, seismic slip propagation and associated fracturing during thrust-related earthquakes may have generated the crackle-like vein texture within the limestone lense (Fig. $7 \mathrm{~h}$ and 10a) and the polished slip surfaces with truncated observed in the Fuans thrust zone (Fig. 4h). Overall, seismological and geodetic observations worldwide agree that the complete spectrum of fault slip behaviors (i.e. from aseismic to seismic slip) may occur at shallow depths within faults showing foliated fabric (Vannucchi et al., 2019). This is consistent with the range of heterogeneous slip behaviors inferred from microstructures within the Fuans thrust (Fig. 10a).

\subsection{Paleofluid origin}

All calcite mineralizations show marked $\delta^{18} \mathrm{O}$ depletion respect to the host rocks (Fig. 8a). This indicates that fluid circulation and calcite precipitation was fast enough to prevent both isotopic buffering and thermal equilibration with the host rock along the thrust (Beaudoin et al., 2014). Therefore, the origin of the fluids responsible of syn-tectonic calcite mineralization can be inferred. Geochemical data are consistent with calcite precipitation from warm to cold meteoric water-derived fluids, which interacted at different extent with Middle Jurassic-Lower Cretaceous host rock. This interpretation is based on the following evidence:

(1) The calculated $\delta^{18} \mathrm{O}$ fluid compositions at the time of vein precipitation range between 1.1\%o and -7.1\%o (Fig. 9b). These values partially overlap those of modern meteoric water and meteoric-derived groundwater of the Jura Mountains (between -5\% and -14\%o, Fig. 9b; Siegenthaler et al., 1983), suggesting meteoric-derived paleofluids. However, the $\delta^{18} \mathrm{O}$ fluid enrichment and the increasing fluid temperatures (Fig. 9b) is consistent with ${ }^{18} \mathrm{O}$ exchange with carbonate rocks at increasing temperatures and depths, according to the geothermal gradient. 
Conversely, the paleofluids with the lowest calculated $\delta^{18} \mathrm{O}$ are also the coldest, consistently with their origin as meteoric waters with very low degree of water rock interaction with the host rock.

(2) The oxygen isotope values of calcite mineralizations are homogeneous (between 22\%o and 24\%o). This suggests that veins and slickenfibers generated at comparable conditions during infiltration of meteoric fluids during tectonic activity and from the same original meteoric fluids, which had interacted to a different extent with the host rocks.

(3) The negative $\delta^{13} \mathrm{C}$ values of slickenfibers, several veins bound by dissolution seams, and cements, compared to those of the local host rocks (Fig. 9a), is consistent with meteoric waters with a contribution of isotopically light carbon derived from biological activity and organic matter oxidation in soils or surface aquifer.

(4) The homogeneous ${ }^{87} \mathrm{Sr} /{ }^{86} \mathrm{Sr}$-isotope value of 0.7072 of the mineralizations (Table S4) indicate interaction with Tithonian-Berriasian limestones (Lower Cretaceous-Upper Jurassic) and/or with Bajocian-Toarcian limestones (Middle Jurassic) $\left({ }^{87} \mathrm{Sr} /{ }^{86} \mathrm{Sr}\right.$-isotope values between 0.7071 and 0.7073; McArthur et al., 2001), which are both crosscut by the Fuans thrust (Fig. 2). The small variations of the ${ }^{87} \mathrm{Sr} /{ }^{86} \mathrm{Sr}$ ratio indicate unchanged $\mathrm{Sr}$ rock source throughout calcite deposition, excluding mixing with uprising deep-seated fluids, which interacted with Triassic and/or Permian basement rocks $\left({ }^{87} \mathrm{Sr} /{ }^{86} \mathrm{Sr}\right.$ values of 7076-0.7084; McArthur et al., 2001).

\subsection{Syntectonic fluid circulation}

Based on the above observations a model of fluid circulation can be proposed. In the early stage of deformation, meteoric water infiltrated downwards and circulated through groundwater aquifers, located above the upward propagating Fuans thrust, in Lower-Cretaceous and MiddleUpper Jurassic limestones, as suggested by ${ }^{87} \mathrm{Sr} /{ }^{86} \mathrm{Sr}$-isotope values (Fig. 12b and Table S4). With increasing depths the fluids warmed (up to at least $54{ }^{\circ} \mathrm{C}$ ) due to the geothermal gradient and became slightly enriched in ${ }^{18} \mathrm{O}$ due to isotopic exchange with limestones (Fig. 8b). Fracturing within fault-related folds promoted the infiltration of previously stored meteoric fluids in the 
thrust process zone of the Fuans thrust (i.e. the fractured zone located ahead the tip of a propagation fault, Vermilye, 1996) and calcite precipitation into fault/fold-related fractures (Beaudoin et al., 2011; Fig. 10b).

Subsequently, upward thrust propagation across the thrust tip generated foliated tectonites along the thrust core, reworking also inherited veins previously precipitated in the process zone (Fig. 12b). Veins oblique to the dissolution seams (Fig. 7a,d), reworked clasts of tectonites and veins (Figs. $8 \mathrm{~b}$ and 10a), and scattered $\delta^{18} \mathrm{O}$ values (Fig. 8a) all suggest a dynamic process in semi-open fluid circulation conditions. Different cathodoluminescence colors among veins (Fig. 8e-h) and crystal zonation (Fig. 8e,g,h) suggest multiple inputs of fluids with slightly different chemical compositions during multiple fracturing episodes and/or slightly changes in fluid chemistry during crystal precipitation. This scenario implies alternating generations of the process zones ahead of the thrust tip and their reworking by thrust propagation and foliated tectonite generation (Fig. 12a). In this context, the limestone lense preserved within the two thrusts splays (Figs. $5 \mathrm{~g}$ and 12a) may be interpreted as a relict of such process zone.

In the latest phase of fluid circulation, the thrust propagated upward and intercepted the Earth's surface and/or shallow groundwater aquifers. The fluid circulation shifted towards an open system, promoting a more efficient and extensive influx of meteoric fluids, (Fig. 12b), a common mechanisms acting within thrust and normal faults breaking Earth's surface (Agosta and Kirschner, 2003; Smeraglia et al., 2018; Lucca et al., 2018). This is consistent with geochemical signatures of slickenfibers, characterized by the lowest precipitation temperatures $\left(<26{ }^{\circ} \mathrm{C}\right)$, calculated $\delta^{18} \mathrm{O}$ paleofluid composition $\left(<-5.4 \%\right.$ ), and $\delta^{13} \mathrm{C}$ values $(<-1.5 \%$ ) (Fig. 9a-c), indicating a clear meteoric signature. In addition, the more homogeneous isotopic composition of slickenfibers (both $\delta^{13} \mathrm{C}$ and $\delta^{18} \mathrm{O}$ ) compared to that of the other mineralizations (Fig. 9a), supports the idea of a more efficient and extensive meteoric fluids infiltration at the time of their formation.

According to geochemical data (Fig. 9a-c) and microstructural observation (Figs. 7h and 8ac), slickenfibers formed at shallower depths and postdated all the others fault-related 
mineralizations, possibly recording the latest movements of the thrust. Despite the network of phyllosicate-rich dissolution seams, which are generally believed to act as barriers for fluid flow (Toussaint et al., 2018), meteoric fluids were able to circulate during the formation of foliated tectonite, precipitating veins and slickenfibers (Fig. 12a,b).

Similar systems, showing progressive opening to superficial meteoric fluids during thrusting/folding, were described in several fold-and-thrust belt (Evans and Fischer, 2012; Beaudoin et al., 2015). In particular, the circulation of meteoric fluids typically occurs within the frontal thrust of fold-and-thrust belts (i.e. Mexican fold-and-thrust belt, Fitz-Diaz et al., 2011; Pyrenees, Lacroix et al., 2014). The lack of circulation of deep-seated fluids along the Fuans thrust can be related to the occurrence of a low-permeability barrier(s) within the stratigraphy, probably consisting of Aalenian shales (i.e. Opalinus Ton; Fig. 1a), which prevent the uprising of deep fluids stored in Triassic and Permian basement rocks.

Conversely from this study, no meteoric-derived fluids were observed in the Mt. Terri thrust, a minor and blind splay of the frontal thrust of the Internal Jura fold-and-thrust belt located $\sim 50 \mathrm{~km}$ towards NE from the study area (Laurich et al., 2014). In particular Clauer et al. (2018) documented syn-tectonic fluids coming from the rocks located nearly in the hangingwall and in the footwall of the Mt. Terri thrust. Such fluid circulation has been related to the low-permeability of Aalenian shales (i.e. Opalinus Ton) cut by the thrust, which acted as a barrier for fluid circulation and crated a system closed to the infiltration of external fluids. This different behavior indicates that, despite the same structural position of thrust faults across a fold-and-thrust belt, syn-tectonic fluid circulation can be strongly affected by thrust displacement value and by the different lithologies cut by the thrust.

\subsection{Deformation depths}

In the proposed model of fluid circulation, meteoric-derived fluids infiltrated downward within the thrust from groundwater aquifers located above the thrust zone. Fluid circulation and 
calcite precipitation was fast enough to prevent isotopic buffering and thermal equilibration with the host rock along the thrust, thus precluding the absolute depth estimation of fault-related mineralization precipitation and thrusting. However, assuming a surface water temperature of 10 ${ }^{\circ} \mathrm{C}$ (i.e. modern temperature of groundwater from springs in the Jura Mountains; Jeannin, 2016) and a geothermal gradients of $30{ }^{\circ} \mathrm{C} / \mathrm{km}$, the modern geothermal gradient measured in boreholes in the Jura Mountains and Molasse basin (Chelle-Michou et al., 2017), we can estimate the minimum depth needed to reach the measured temperatures. Most fault-related mineralizations show precipitation temperatures between $\sim 20$ and $\sim 40{ }^{\circ} \mathrm{C}$. Therefore, the minimum depths necessary for the paleofluids to acquire such temperatures range between $\sim 0.3 \mathrm{~km}$ and $\sim 1 \mathrm{~km}$ (Fig. 12b). The lowest recorded temperature of $10^{\circ} \mathrm{C}$ indicate a paleofluid essentially reflecting shallow groundwater surface temperatures (Fig. 12b), while the highest temperature of $54{ }^{\circ} \mathrm{C}$ extend the minimum paleofluid circulation to a depth of $\sim 1.4 \mathrm{~km}$. These shallow deformation depths are consistent with the clay mineralogical from host rock and minor reverse faults in the Fuans thrust zone. Indeed, the occurrence of smectite (or smectite rich illite /smectite mixed layers) and kaolinite suggest very limited burial diagenesis and low temperatures of the sediment in the study area. Thus, we suggest that in the study outcrop thrusting initiated at burial depths no shallower than $\sim 1.4 \mathrm{~km}$ (Fig. 12b). However, if we only consider the $\sim 170$ m-thick Kimmeridgian deposits located above the Fuans thrust in the study area and the maximum preserved thickness of $\sim 400 \mathrm{~m}$ of Upper-Lower Cretaceous deposits in the Jura Mountains (Fig. 1; Strasser et al., 2016), the Fuans thrust should have been buried below a $\sim 570$ m-thick sedimentary succession. This difference can be explained by the occurrence of Miocene Molasse basin deposits thicker than those currently exposed, by thrust sheet emplacement, which thickened the sedimentary succession and increased the overburden before the Fuans thrust activation, and/or by a combination of the two mechanisms.

\section{Conclusions}


Structural and microstructural observations combined with geochemical data along the frontal thrust of the internal part of the Jura foreland fold-and-thrust belt show that:

(1) Thrust-related folding was accomodated both by layer-parallel shortening and layerparallel shear, which generated stylolites roughly perpendicular respect to bedding, S-CC' fabric in marly limestone interbeds, and flexural slip along bedding surfaces. In addition, minor reverse, strike-slip, and normal faults cross-cut the thrust-related folds. The occurrence of such features can lead to both displacement and shortening underestimation during cross section balancing across fold-and-thrust belts.

(2) Dissolution seams, veins perpendicular and oblique to them, cements, and slickenfibers within the foliated tectonites along the Fuans thrust core indicate cycles of mutually overprinting pressure-solution and brittle processes, such as frictional sliding and fracturing/veining, without significant cataclasis of the host rock. These deformation mechanisms reflect different thrust slip behaviors: pressure-solution suggest continuous aseismic creep by ductile elastic strain dissipation; micrometer crack-and-seal opening increments along slickenfibers are likely the product of deformation at slow slip rates, probably aseismic; crackle-like vein texture and polished slip surfaces with truncated clasts may be the result of seismic fracturing during earthquakes. The ongoing aseismic anticline growth in the Jura fold-and-thrust belt can be related to slow (i.e. aseismic) pressure-solution processes and micrometer slip within slickenfibers along thrusts cutting across the sedimentary cover. On the contrary, during thrust-related earthquakes fast seismic rupture propagation and associated fracturing may have generated the crackle-like vein texture polished slip surfaces with truncated clasts.

(3) Fluid circulation was characterized by a progressive opening of the system, characterized by a more efficient and extensive meteoric fluids circulation. Calcite precipitated at temperatures between $54{ }^{\circ} \mathrm{C}$ and $10{ }^{\circ} \mathrm{C}$ from meteoric fluids. Lower $\delta^{13} \mathrm{C}$ in the colder paleofluids are interpreted as a clear meteoric water signature derived from organic matter oxidation in soils. This indicates a progressively more efficient infiltration of meteoric fluids during upward thrust 
propagation/exhumation. The homogeneous ${ }^{87} \mathrm{Sr} /{ }^{86} \mathrm{Sr}$-isotope value of 0.7072 excludes the uprising of deep-seated fluids. More specifically, fluid interaction with Triassic and/or Permian basement rocks can be excluded, supporting the idea of a low-permeability barrier at depth probably consisting of Aalenian shales. Considering the highest recorded temperature of $54{ }^{\circ} \mathrm{C}$ and assuming the modern geothermal gradient of $30{ }^{\circ} \mathrm{C} / \mathrm{km}$, thrusting and syn-tectonic fluid circulation within the exposed study outcrop initiated at burial depths of at least $\sim 1.4 \mathrm{~km}$.

(4) Frontal thrusts may act as conduits for the downward infiltration of shallow meteoricderived fluids, which channelize along thrust during syntectonic fluid flow in an open system, as observed in other fold-and-thrust belt worldwide.

\section{Acknowledgements}

This work has been funded by Borsa di Perfezionamento Estero 2017 (Sapienza) and Andy Whitham CASP Fieldwork Award 2019 to L. Smeraglia. We thank G. Viola, O. Lacombe, J. Mosar, M. Schori, and A. Sommaruga for constructive discussions and suggestions. We thank H. Bourque and L. Etienne, for help during optical microscope and cathodoluminescence analyses. We thank Virginie Moutalier and Marguerite Perrey for help during XRD analyses, R. Coltat and L. De Hoÿm de Marien for help during stable isotopes analyses. We acknowledge Midland Valley for providing the 2017 academic license (Sapienza) for the software MOVE. We thank TSLab \& Geoservices and Didier Convert-Gaubier for thin sections preparation. We thanks the Editor P. Agard, N. Beaudoin and J. P. Gratier for their constructive comments, which helped to improve and clarify the paper.

\section{References}

Affolter, T., \& Gratier J.P. (2004). Map view retrodeformation of an arcuate fold-and-thrust belt: The Jura case. Journal of Geophysical Research: Solid Earth 109, B3. 
Agosta, F., \& Kirschner, D. L. (2003). Fluid conduits in carbonate-hosted seismogenic normal faults of central Italy. Journal of Geophysical Research: Solid Earth, 108(B4).

Allmendinger, R.W. (1998). Inverse and forward numerical modeling of trishear fault-propagation folds. Tectonics, 17, 640-656.

Baer, M., Deichmann, N., Braunmiller, J., Husen, S., Fäh, D., Giardini, D., ... \& Wiemer, S. (2005). Earthquakes in Switzerland and surrounding regions during 2004. Eclogae Geologicae Helvetiae, 98(3), 407-418.

Beaudoin, N., Bellahsen, N., Lacombe, O., \& Laurent E. (2011). Fracture-controlled paleohydrogeology in a basement-cored, fault-related fold: Sheep Mountain Anticline, Wyoming, United States. Geochemistry, Geophysics, Geosystems, 2011, vol. 12, no 6.

Beaudoin, N., Bellahsen, N., Lacombe, O., Emmanuel, L., \& Pironon, J. (2014). Crustal-scale fluid flow during the tectonic evolution of the Bighorn Basin (Wyoming, USA). Basin Research, 26(3), 403-435.

Beaudoin, N., Huyghe, D., Bellahsen, N., Lacombe, O., Emmanuel, L., Mouthereau, F., \& Ouanhnon, L. (2015). Fluid systems and fracture development during syn-depositional fold growth: An example from the Pico del Aguila anticline, Sierras Exteriores, southern Pyrenees, Spain. Journal of Structural Geology, 70, 23-38.

Becker, A. (2000). The Jura Mountains - an active foreland fold-and-thrust belt?. Tectonophysics, $321(4), 381-406$.

Bernasconi S.M., Müller I. A., Bergmann K.D., Breitenbach S. F. M., Fernandez, A., Hodell D. A., Jaggi M., Meckler A.N. Millan I., and Ziegler M. (2018) Reducing uncertainties in carbonate clumped isotope analysis through consistent carbonate-based standardization. Geochemistry Geophysics Geosystems 19. https://doi.org/10.1029/2017GC007385.

Cawood, A. J., \& Bond, C. E. (2018). 3D mechanical stratigraphy of a deformed multi-layer: linking sedimentary architecture and strain partitioning. Journal of Structural Geology, 106, 54-69. 
Cawood, A. J., \& Bond, C. E. (2019). Broadhaven revisited: a new look at models of fault-fold interaction. Geological Society, London, Special Publications, 487, SP487-11.

Chelle-Michou, C., Do Couto, D., Moscariello, A., Renard, P., \& Rusillon, E. (2017). Geothermal state of the deep Western Alpine Molasse Basin, France-Switzerland. Geothermics, 67, 4865.

Clauer, N., Techer, I., Nussbaum, C., \& Laurich, B. (2018). Geochemical signature of paleofluids in microstructures from Main Fault in the Opalinus Clay of the Mont Terri rock laboratory, Switzerland. In: Mont Terri Rock laboratory, 20 years. Swiss Journal of Geosceince 2018, 107-130.

Cooper, M. (2007). Structural style and hydrocarbon prospectivity in fold and thrust belts: a global review. Special Publication-Geological Society of London, 272, 447.

Crognier, N., Hoareau, G., Aubourg, C., Dubois, M., Lacroix, B., Branellec, M., Callot J.P. \& Vennemann, T. (2018). Syn- orogenic fluid flow in the Jaca basin (south Pyrenean fold and thrust belt) from fracture and vein analyses. Basin Research, 30(2), 187-216.

Davis, D., Suppe, J., \& Dahlen, F. A. (1983). Mechanics of fold-and-thrust belts and accretionary wedges. Journal of Geophysical Research: Solid Earth, 88(B2), 1153-1172.

Delvaux, D., Sperner, B., 2003. New aspects of tectonic stress inversion with reference to the TENSOR program. Geol. Soc. Spec. Publ. 212, 75-100.

Evans, M. A., \& Fischer, M. P. (2012). On the distribution of fluids in folds: A review of controlling factors and processes. Journal of Structural Geology, 44, 2-24.

Fagereng, Å., \& Byrnes, G. (2015). A range of fault slip styles on progressively misoriented planes during flexural-slip folding, Cape Fold Belt, South Africa. Journal of Structural Geology, 70, 156-169.

Fagereng, Å., Remitti F., \& Sibson R.H. (2011). "Incrementally developed slickenfibersGeological record of repeating low stress-drop seismic events?." Tectonophysics 510.3-4, 381-386. 
Faulkner, D. R., Jackson, C.A.L., Lunn, R. J., Schlische, R. W., Shipton, Z. K., Wibberley, C. A. J., \& Withjack, M. O. (2010). A review of recent developments concerning the structure, mechanics and fluid flow properties of fault zones. Journal of Structural Geology, 32(11), 1557-1575.

Fernandez, A., Müller I.A., Rodriguez-Sanz L., van Dijk I., Looser N., \& Bernasconi S.M., (2017) Reassessment of the Precision of Carbonate Clumped Isotope Measurements: Implications for Calibrations and Paleoclimate Reconstructions, Geochemistry, Geophysics, Geosystems, DOI:10.1002/2017GC007106

Fitz-Diaz, E., Hudleston, P., Siebenaller, L., Kirschner, D., Camprubí, A., Tolson, G., \& Puig, T. P. (2011). Insights into fluid flow and water-rock interaction during deformation of carbonate sequences in the Mexican fold-thrust belt. Journal of Structural Geology, 33(8), 1237-1253.

Fondriest, M., Aretusini, S., Di Toro, G., \& Smith, S. A. (2015). Fracturing and rock pulverization along an exhumed seismogenic fault zone in dolostones: The Foiana Fault Zone (Southern Alps, Italy). Tectonophysics, 654, 56-74.

Fondriest, M., Smith, S. A., Candela, T., Nielsen, S. B., Mair, K., \& Di Toro, G. (2013). Mirrorlike faults and power dissipation during earthquakes. Geology, 4l(11), 1175-1178.

Ghisetti, F., Kirschner, D.L., Vezzani, L., \& Agosta, F., (2001). Stable isotope evidence for contrasting paleofluid circulation in thrust faults and normal faults of the central Apennines, Italy. J. Geophys. Res.106, 8811-8825.

Giamboni, M., Wetzel, A., Nivière, B., \& Schumacher, M. (2004). Plio-Pleistocene folding in the southern Rhinegraben recorded by the evolution of the drainage network (Sundgau area; northwestern Switzerland and France). Eclogae Geologicae Helvetiae, 97(1), 17-31.

Gratier, J. P., \& Gamond, J. F. (1990). Transition between seismic and aseismic deformation in the upper crust. Geological Society, London, Special Publications, 54(1), 461-473. 
Gratier, J. P., Renard, F., \& Labaume, P. (1999). How pressure solution creep and fracturing processes interact in the upper crust to make it behave in both a brittle and viscous manner. Journal of Structural Geology, 21(8-9), 1189-1197.

Gratier, J. P., Thouvenot, F., Jenatton, L., Tourette, A., Doan, M. L., \& Renard, F. (2013). Geological control of the partitioning between seismic and aseismic sliding behaviours in active faults: Evidence from the Western Alps, France. Tectonophysics, 600, 226-242.

Grelaud, S., Buil, D., Hardy, S., \& Frizon de Lamotte, D. (2000). Trishear kinematic model of fault-propagation folding and sequential development of minor structures; the Oupia Anticline (NE Pyrenees, France) case study. Bulletin de la Société Géologique de France, 171(4), 441-449.

Gutiérrez-Alonso, G., \& Gross, M. R. (1999). Structures and mechanisms associated with development of a fold in the Cantabrian Zone thrust belt, NW Spain. Journal of Structural Geology, 21(6), 653-670.

Hallam, A., Grose, J. A., \& Ruffell, A. H. (1991). Palaeoclimatic significance of changes in clay mineralogy across the Jurassic-Cretaceous boundary in England and France. Palaeogeography, Palaeoclimatology, Palaeoecology, 81(3-4), 173-187.

Hardy, S., \& Ford, M. (1997). Numerical modeling of trishear fault propagation folding. Tectonics, 16(5), 841-854.

Jeannin, P. Y., Hessenauer, M., Malard, A., \& Chapuis, V. (2016). Impact of global change on karst groundwater mineralization in the Jura Mountains. Science of the Total Environment, $541,1208-1221$.

Joachimski, M. M. (1994). Subaerial exposure and deposition of shallowing upward sequences: evidence from stable isotopes of Purbeckian peritidal carbonates (basal Cretaceous), Swiss and French Jura Mountains. Sedimentology, 41(4), 805-824.

Kim, S. T., \& O'Neil, J. R. (1997). Equilibrium and nonequilibrium oxygen isotope effects in synthetic carbonates. Geochimica et Cosmochimica Acta, 61(16), 3461-3475. 
Kirschner, D. L., \& Kennedy, L. A. (2001). Limited syntectonic fluid flow in carbonate-hosted thrust faults of the Front Ranges, Canadian Rockies, inferred from stable isotope data and structures. Journal of Geophysical Research: Solid Earth, 106(B5), 8827-8840.

Kodaira, S., No, T., Nakamura, Y., Fujiwara, T., Kaiho, Y., Miura, S., Takahashi, N., Kaneda, Y., \& Taira A. (2012). Coseismic fault rupture at the trench axis during the 2011 Tohoku-oki earthquake. Nature Geoscience, 5(9), 646-650.

Labaume, P., Kastner, M., Trave, A., \& Henry, P. (1997). Carbonate veins from the décollement zone at the toe of the northern Barbados accretionary prism: microstructure, mineralogy, geochemistry, and relations with prism structures and fluid regime. In Proceedings-ocean drilling program scientific results (pp. 79-96). National science foundation.

Lacroix, B., Buatier, M., Labaume, P., Travé, A., Dubois, M., et al. (2011). Microtectonic and geochemical characterization of thrusting in a foreland basin: Example of the SouthPyrenean orogenic wedge (Spain). Journal of Structural Geology, 33(9), 1359-1377.

Lacroix, B., Travé, A., Buatier, M., Labaume, P., Vennemann, T., \& Dubois, M. (2014). Syntectonic fluid-flow along thrust faults: Example of the South-Pyrenean fold-and-thrust belt. Marine and Petroleum Geology, 49, 84-98.

Laurich, B., Urai, J. L., Desbois, G., Vollmer, C., \& Nussbaum, C. (2014). Microstructural evolution of an incipient fault zone in Opalinus Clay: Insights from an optical and electron microscopic study of ion-beam polished samples from the Main Fault in the Mt-Terri Underground Research Laboratory. Journal of Structural Geology, 67, 107-128.

Leclère, H., Cappa, F., Faulkner, D., Fabbri, O., Armitage, P., \& Blake, O. (2015). Development and maintenance of fluid overpressures in crustal fault zones by elastic compaction and implications for earthquake swarms. Journal of Geophysical Research: Solid Earth, 120(6), $4450-4473$. 
Lucca, A., Storti, F., Molli, G., Muchez, P., Schito, A., et al. (2018). Seismically enhanced hydrothermal plume advection through the process zone of the Compione extensional Fault, Northern Apennines, Italy. Bulletin, 131(3-4), 547-571.

Madritsch, H., Preusser, F., Fabbri, O., Bichet, V., Schlunegger, F., \& Schmid, S. M. (2010). Late Quaternary folding in the Jura Mountains: evidence from syn-erosional deformation of fluvial meanders. Terra Nova, 22(2), 147-154.

Madritsch, H., Schmid, S. M., \& Fabbri, O. (2008). Interactions between thin- and thick-skinned tectonics at the northwestern front of the Jura fold-and-thrust belt (eastern France). Tectonics, 27(5).

Malz, A., Madritsch, H., \& Kley, J. (2015). Improving 2D seismic interpretation in challenging settings by integration of restoration techniques: A case study from the Jura fold-and-thrust belt (Switzerland). Interpretation, 3(4), SAA37-SAA58.

McArthur, J. M., Howarth, R. J., \& Bailey, T. R. (2001). Strontium isotope stratigraphy: LOWESS version 3: best fit to the marine Sr-isotope curve for 0-509 Ma and accompanying look-up table for deriving numerical age. The Journal of Geology, 109, 155-170.

Melosh, B. L., Rowe, C. D., Smit, L., Groenewald, C., Lambert, C. W., \& Macey, P. (2014). Snap, Crackle, Pop: Dilational fault breccias record seismic slip below the brittle-plastic transition. Earth and Planetary Science Letters, 403, 432-445.

Mosar, J., \& Suppe, J. (1992). Role of shear in fault-propagation folding. In Thrust tectonics (pp. 123-132). Springer, Dordrecht.

Nissen, E., Tatar, M., Jackson, J. A., \& Allen, M. B. (2011). New views on earthquake faulting in the Zagros fold-and-thrust belt of Iran. Geophysical Journal International, 186(3), 928-944.

Philippe, Y., Colletta, B., Deville, E., \& Mascle, A. (1996). The Jura fold-and-thrust belt: a kinematic model based on map-balancing. Mémoires du Muséum national d'histoire naturelle, 170, 235-261. 
Renard, F., Andréani, M., Boullier, A. M., \& Labaume, P. (2005). Crack-seal patterns: records of uncorrelated stress release variations in crustal rocks. Geological Society, London, Special Publications 243(1), 67-79.

Renard, F., Ortoleva, P., \& Gratier, J. P. (1997). Pressure solution in sandstones: influence of clays and dependence on temperature and stress. Tectonophysics, 280(3-4), 257-266.

Schori, M., Mosar, J., \& Schreurs, G. (2015). Multiple detachments during thin-skinned deformation of the Swiss Central Jura: a kinematic model across the Chasseral. Swiss Journal of Geosciences 108, 327-343.

Siegenthaler, U., Schotterer, U., \& Muller, I. (1983). Isotopic and chemical investigations of springs from different karst zones in the Swiss Jura. Isotope Hydrology, proceedings of a symposium. 12-16 September, 1983.

Smeraglia, L., Bernasconi, S. M., Berra, F., Billi, A., Boschi, C., et al. (2018). Crustal-scale fluid circulation and co-seismic shallow comb-veining along the longest normal fault of the central Apennines, Italy. Earth and Planetary Science Letters, 498, 152-168

Sommaruga, A. (1996). Geology of the central Jura and the molasse basin (Doctoral dissertation, Université de Neuchâtel).

Strasser, A., Charollais, J., Conrad, M. A., Clavel, B., Pictet, A., \& Mastrangelo, B. (2016). The Cretaceous of the Swiss Jura Mountains: an improved lithostratigraphic scheme. Swiss Journal of Geosciences, 109(2), 201-220.

Strasser, A., Vedrine, S., \& Stienne, N. (2012). Rate and synchronicity of environmental changes on a shallow carbonate platform (Late Oxfordian, Swiss Jura Mountains). Sedimentology, $59(1), 185-211$.

Tanner, P. G. (1989). The flexural-slip mechanism. Journal of Structural Geology, 11(6), 635655.

Tavani, S., Storti, F., Lacombe, O., Corradetti, A., Muñoz, J. A., \& Mazzoli, S. (2015). A review of deformation pattern templates in foreland basin systems and fold-and-thrust belts: 
Implications for the state of stress in the frontal regions of thrust wedges. Earth-Science Reviews, 141, 82-104.

Tesei, T., Collettini, C., Viti, C., \& Barchi, M. R. (2013). Fault architecture and deformation mechanisms in exhumed analogues of seismogenic carbonate-bearing thrusts. Journal of Structural Geology, 55, 167-181.

Thouvenot, F., Fréchet, J., Tapponnier, P., Thomas, J. C., Le Brun, B., Ménard, G., Lacassin, R., Jenatton, L., Grasso, J-R., Coutant, O., Paul, A. \& Hatzfeld, D. (1998). The ML 5.3 Epagny (French Alps) earthquake of 1996 July 15: a long-awaited event on the Vuache Fault. Geophysical Journal International 135(3), 876-892.

Toussaint, R., Aharonov, E., Koehn, D., Gratier, J. P., Ebner, M., et al. (2018). Stylolites: A review. Journal of Structural Geology 114, 163-195.

Travé, A., Labaume, P., Calvet, F., Soler, A., Tritlla, J., Buatier, M., ... \& Briqueu, L. (1998). Fluid migration during Eocene thrust emplacement in the south Pyrenean foreland basin (Spain): an integrated structural, mineralogical and geochemical approach. Geological Society, London, Special Publications, 134(1), 163-188.

Ukar, E., \& Laubach, S. E. (2016). Syn-and postkinematic cement textures in fractured carbonate rocks: Insights from advanced cathodoluminescence imaging. Tectonophysics, 690, 190205.

Ustaszewski, K., \& Schmid, S. M. (2006). Control of preexisting faults on geometry and kinematics in the northernmost part of the Jura fold-and-thrust belt. Tectonics, 25, TC 5003, $1-26$.

Vannucchi, P. (2019). Scaly fabric and slip within fault zones. Geosphere 15, 342-356.

Vannucchi, P., Remitti, F., Bettelli, G., Boschi, C., \& Dallai, L. (2010). Fluid history related to the early Eocene-middle Miocene convergent system of the Northern Apennines (Italy): Constraints from structural and isotopic studies. Journal of Geophysical Research: Solid Earth, 115(B5). 
Vermilye, J. (1996) The growth of natural fracture systems: A fracture mechanics approach. Ph.D thesis. Columbia University, New York.

Vrolijk, P., Fisher, A., \& Gieskes, J. (1991). Geochemical and geothermal evidence for fluid migration in the Barbados accretionary prism (ODP Leg 110). Geophysical Research Letters, 18(5), 947-950.

Walpersdorf, A., Baize, S., Calais, E., Tregoning, P., \& Nocquet, J. M. (2006). Deformation in the Jura Mountains (France): First results from semi-permanent GPS measurements. Earth and Planetary Science Letters, 245(1-2), 365-372.

Ziegler, P. A., \& Fraefel, M. (2009). Response of drainage systems to Neogene evolution of the Jura fold-thrust belt and Upper Rhine Graben. Swiss journal of geosciences, 102(1), 57-75. 


\section{Figure captions}

Figure 1. (a) Simplified geological map and stratigraphy (Val de Ruz section, Sommaruga, 1996) of the exposed rocks of the Jura fold-and-thrust belt (b) Geological cross section (modified after Sommaruga, 1996) across the Jura fold-and-thrust belt.

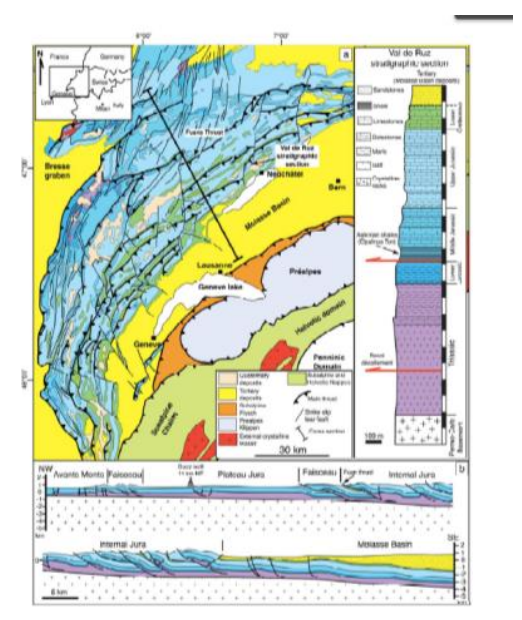

Figure 2. (a) Geological map of the study area (field mapping at 1:10,000 scale) and stratigraphy of the exposed sedimentary succession. (b) Geological sections across the Fuans thrust.

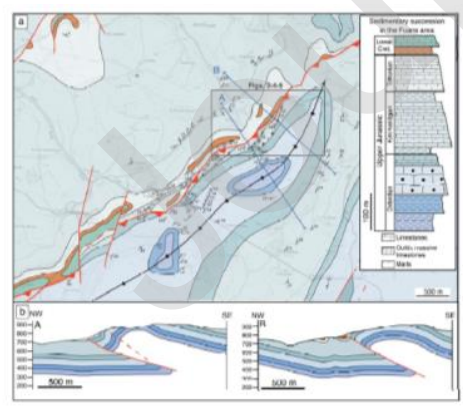


Figure 3. (a) Detailed geological map and cross section of the western part of the study area. (b) Lower Schmidt hemisphere plot of fault-slip data attitude and slip vectors for the minor reverse faults thrust cutting the recumbent limb of the footwall syncline $(1,2)$ and the Fuans thrust $(3,4)$. (c) Detail of the minor reverse faults cutting through the recumbent limb of the footwall syncline. (d) Detail of the Fuans thrust. Note the overturned beds of Tithonian deposits in the footwall. (e) Panoramic view of the hanging-wall syncline. (f) Hanging-wall syncline hinge characterized by overturned limbs crosscut by minor normal faults or by sheared bedding surfaces with undetermined kinematics. (g) Hanging-wall syncline hinge characterized by minor reverse faults and bedding surfaces characterized by flexural slip. (h) Detail of minor reverse faults branching upward from bedding surface characterized by flexural slip.

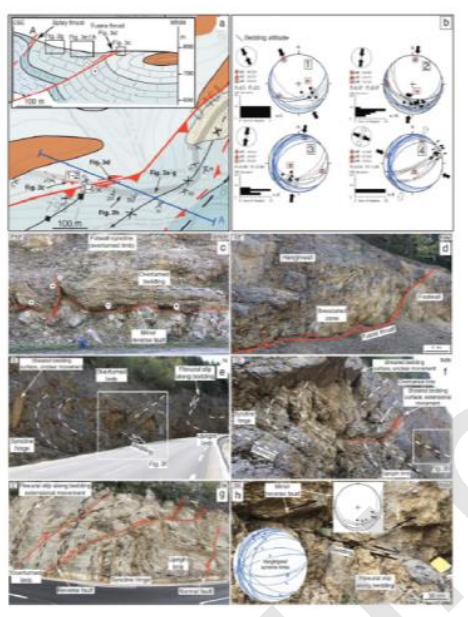

Figure 4. (a) Detailed geological map and cross section of the central part of the study area. (b) Lower Schmidt hemisphere plot of fault-slip data attitude and slip vectors for minor strikeslip faults cutting the hanging-wall syncline upright limb (1), minor normal faults cutting through the hanging-wall syncline overturned limb (2), normal faults cutting through the hanging-wall syncline upright limb (3), and minor reverse faults cutting through a brecciated 
zone (4). (c) Panoramic view of the hanging-wall syncline hinge. (d) Detail of the minor normal faults cutting through the hanging-wall syncline overturned limb. Inset shows calcite slickenfibers indicating extensional kinematics. (e) Bedding-parallel stylolites. (f) Detail of S-CC' fabric in the hanging-wall syncline upright limb. (g) Minor reverse faults cutting through a brecciated zone. (h) Detail of minor reverse fault with a clay-rich layer localized along fault plane and polished slip surface with truncated clasts.

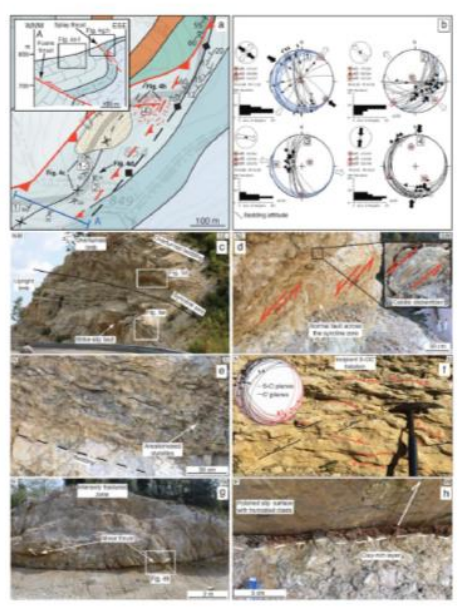

Figure 5. (a) Detailed geological map and cross section of the eastern part of the study area. (b) Lower Schmidt hemisphere plot of fault-slip data attitude and slip vectors for minor strike slip faults (1), gently-dipping reverse faults (2), subvertical reverse faults (3), and normal faults (4) cutting the hanging-wall anticline forelimb, for the Fuans thrust planes (5), and for evidence of a few re-activated thrust planes showing left-lateral normal and sinistral displacements (6). (c) Panoramic view of the hanging-wall anticline forelimb. Lower hemisphere Schmidt nets for the hanging-wall syncline limbs showing flexural slip evidence and stylolites roughly perpendicular to bedding (see Fig. S1f). (d) Subvertical minor reverse 
fault, oriented roughly perpendicular to bedding, cutting through the anticline hinge. (e,f,g) Hanging-wall anticline forelimb cut by the Fuans thrust. Note that Fuans thrust branching into two splays, which enclose a fractured/veined limestone lense (g). (h) Detail of the fault core of the Fuans thrust. Inset shows lower Schmidt hemisphere plot of slip data attitude and slip vectors of S-CC' tectonites within the Fuans thrust core.

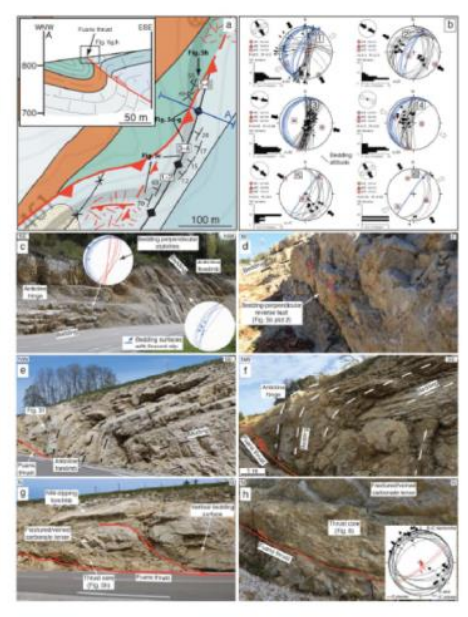

Figure 6. Fault rocks associated with the Fuans thrust. (a) Detail of the fault core of the Fuans thrust. (b,c) Foliated tectonite in marls at the boundary with the fractured/veined limestone lense (a). Inset in (c) shows lower Schmidt hemisphere plot of slip data attitude and slip vectors of S- and C-planes of the foliated tectonite. (d,e) Foliated tectonite in limestone. (f) Calcite slickenfibers along C-plane in the foliated tectonite in limestone. (g) High-resolution hand sample scan of foliated tectonite in marl showing a pervasive network of dissolution seams. (h,i) High-resolution hand sample scan of foliated tectonite in limestone showing dissolution seams bounding calcite veins. Note that veins are perpendicular (h) or oblique (i) respect to dissolution seams. (h) High-resolution hand sample scan of the fractured/veined 
limestone lense cross-cut by calcite veins showing random orientation, without evidence of dissolution seams.

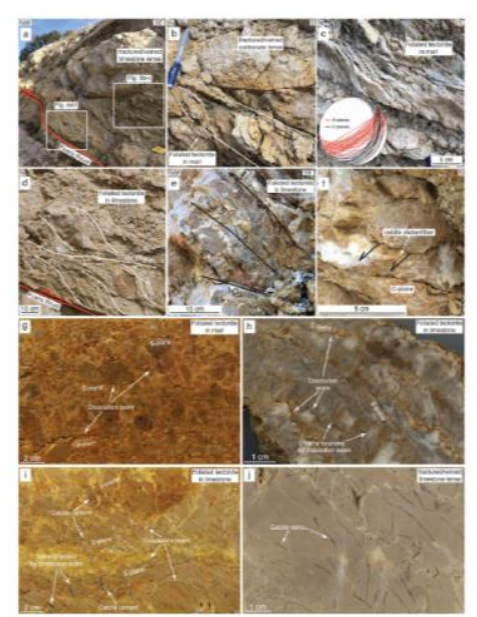

Figure 7. (a,b) Veins bounded by dissolution seams. These veins are perpendicular or oblique to dissolution seams. Several veins cross-cut dissolution seams. Dissolution seams show both teeth-shaped and flat morphologies. Note the concentration of insoluble brown to dark material (mainly phyllosilicates) within dissolution seams. (c-f) Dissolution seams delineating lozenge-shaped host rock sigmoids and reworking veins or clasts of tectonites. Note the teeth-shaped morphology of dissolution seams and voids within host rock sigmoids filled by calcite cement. (g) Detail of the calcite cement showing dissolution seams along the boundary between crystals and between crystals and clasts. (h) Millimeter-thick dilational jogs between parallel dissolution seams, activated as shear surfaces, filled by blocky calcite crystals. 


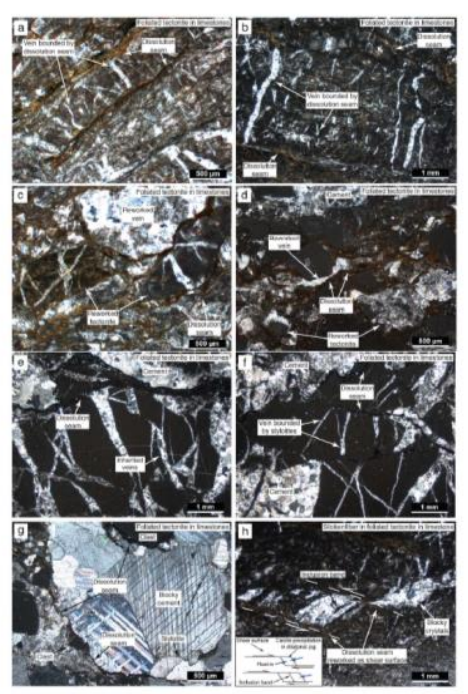

Figure 8. (a-c) Slickenfiber textures showing multiple calcite layers showing fibrous crystals and bounded by shear surfaces. Note the inclusion bands at high angles $\left(\sim 60^{\circ}-70^{\circ}\right)$ to the shear surfaces (a), and shear surfaces localized along inherited dissolution seams (g). (d) Veins within the fractured/veined limestones lense filled by blocky calcite crystals, showing mutual cross-cutting relationships and lack of incremental opening. These veins generate a crackle-like texture and are not associated with dissolution seams. (e,f) Veins bounded by dissolution seams (both oblique and perpendicular to dissolution seams) cutting through host rock relicts. Note the mutual crosscutting relationships between veins bounded by dissolution seams. Microphotographs under cathodoluminescence light. (g,h) Host rock relicts affected by dissolution seams, crosscut by veins bounded by dissolution seams, and surrounded by calcite cement. Note the blocky crystals of calcite cement showing zonation. Microphotographs under cathodoluminescence light. 


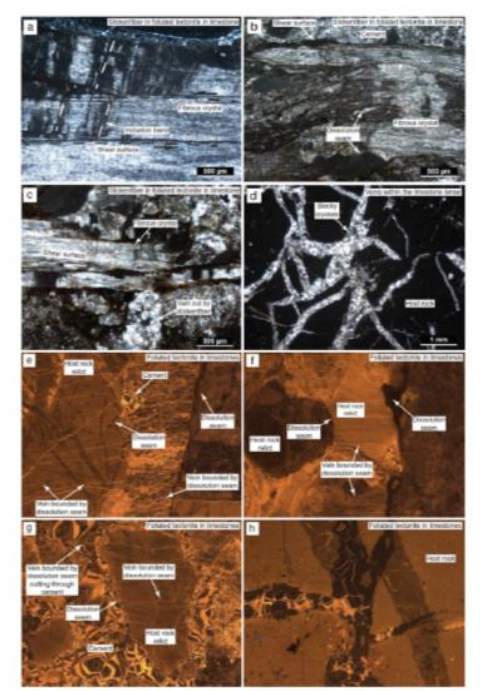

Figure 9. (a) $\delta^{13} \mathrm{C}\left(\%\right.$ V-PDB) versus $\delta^{18} \mathrm{O}$ (\%o V-SMOW) diagram for the analyzed samples from various mineralizations (veins and slickenfibers) and local host rocks in the Fuans thrust. Note the average $\delta^{18} \mathrm{O}$ depletion of $\sim 4.1 \%$ between fault-related mineralizations and host rock. (b) Oxygen isotope fractionation during equilibrium precipitation: $\delta^{18} \mathrm{O}$ of faultrelated mineralizations and paleofluid compositions (curves) as a function of temperature. Half of the $\delta^{18} \mathrm{O}$ calculated paleofluid compositions overlaps with $\delta^{18} \mathrm{O}$ composition of modern meteoric water and groundwater within the Jura Mountains. Note that warmer fluids are characterized by higher $\delta^{18} \mathrm{O}$ paleofluid composition indicating increasing interaction with carbonate rock at increasing temperatures (i.e. at increasing depths). (c) Variation of $\delta^{13} \mathrm{C}$ as a function of temperatures. Note that colder fluids are characterized by lower $\delta^{13} \mathrm{C}$ values, indicating an increase of light ${ }^{12} \mathrm{C}$ carbon. 


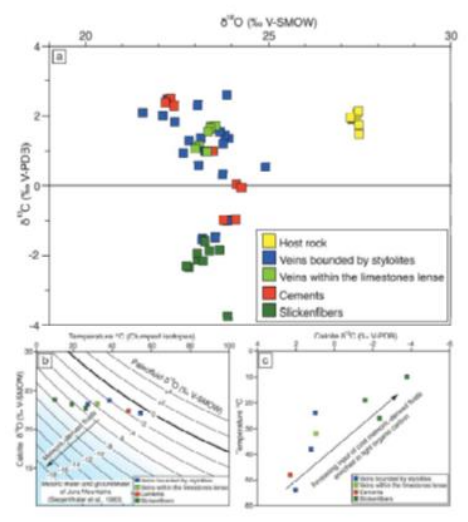

Figure 10. 2D kinematic model for the development of the Fuans thrust and associated folds developed using MOVE 2017 software. (a) Geological section constructed from field data and illustrating the inferred structural framework at depth. (b) In the early stage of deformation, shortening was firstly accomodated by folding above the tip point of the Fuans thrust, forming an anticline-syncline pair. (c) Further shortening was accomodated by fold tightening and overturning, followed by Fuans thrust breakthrough across the anticlinesyncline pair. (c) During progressive deformation, a splay thrust started to branch from the Fuans thrust and, above its tip point, a new anticline-syncline pair was generated. (e) Further shortening was accomodated by fold tightening and by splay thrust breakthrough. (f) Setting after exhumation and erosion. Compare panel (f) with panel (a). 


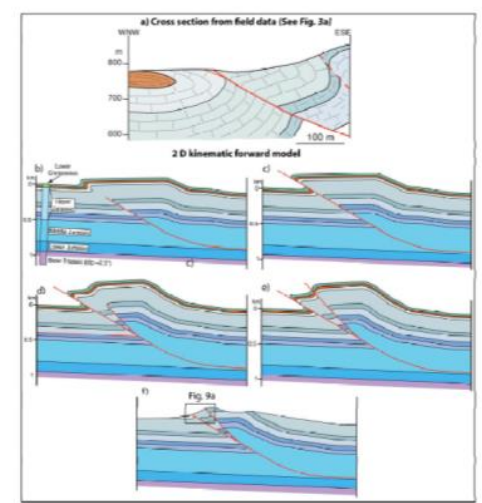

Figure 11. Deformation mechanisms activated during folding and thrusting. (a) During folding layer-parallel shortening and shear generated, respectively, stylolites roughly perpendicular to bedding and flexural slip along bedding. (b) During Fuans thrust breakthrough minor reverse faults generated in the footwall syncline. Strike-slip faults generated during thrust activation and/or post-thrusting. (c) During folding in the hangingwall, related to splay thrust propagation, minor reverse faults and normal faults generated in the syncline hinge and in fold limbs. Note that subvertical minor revers faults cutting the anticline hinge probably re-activated, by shearing, inherited stylolites. In places, inherited strike-slip fault were offset by bedding surfaces sheared by flexural slip. (d) During splay thrust breakthrough, minor reverse faults generated in the anticline hinge and forelimb. Strike-slip faults generated during thrust activation and/or post-thrusting. 


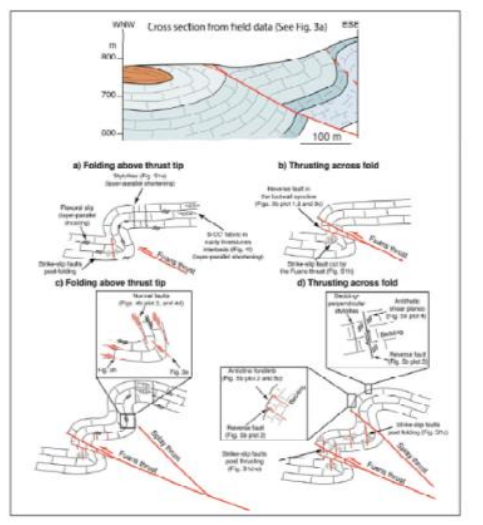

Figure 12. (a) Main microstructures within the foliated tectonite in limestones and schematic evolutionary model for foliated tectonite generation. (b) Schematic model showing fluid circulation during progressive upward propagation/exhumation along the Fuans thrust. Note the progressive opening of the system, characterized by more efficient downward flow of colder meteoric fluids located within shallow groundwater aquifers. Minimum deformation depths calculated using paleofluid temperatures (from clumped isotopes) and assuming geothermal gradients of $30{ }^{\circ} \mathrm{C} / \mathrm{km}$ from exploration wells (Chelle-Michou et al., 2017).

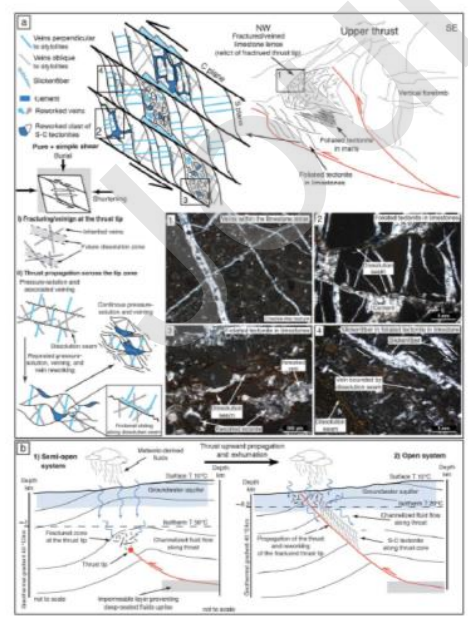


Figure S1. (a) Calcite slickenfibers indicating extensional movement along a normal fault cutting through the syncline hinge. Normal fault indicated in Fig. 3f. (b) Calcite slickenfibers indicating extensional movement along bedding surface in the overturned limb of the hanging-wall syncline. Bedding surface indicated in Fig. 3g. (c) Minor normal fault, showing right-lateral normal displacement, cutting the upright limb of the hanging-wall syncline. Note the strike-slip faults (on the right) cutting and post-dating the normal faults. (d,e) Dextral strike-slip faults cutting the Fuans thrust planes. (f) Stylolites roughly perpendicular to bedding. (g) Minor subvertical reverse fault cutting the anticline forelimb (see Fig. 5d). Note the fault surface showing both wrinkled appearance, typical of stylolitic surfaces, and mechanical striation. (h) Fuans thrust cutting through dextral strike-slip faults.

Figure S2. XRD diffraction pattern of whole rock analyses.

Figure S3. XRD diffraction pattern of $<2 \mu \mathrm{m}$ fraction analyses. 